\title{
Amyloid- $\beta$ Peptide Is Needed for cGMP-Induced Long-Term Potentiation and Memory
}

\author{
Agostino Palmeri, ${ }^{1 \star}$ - Roberta Ricciarelli, ${ }^{2 \star}$ Walter Gulisano, ${ }^{1}$ Daniela Rivera, ${ }^{2}$ Claudia Rebosio, ${ }^{3}$ Elisa Calcagno, ${ }^{2}$ \\ @Maria Rosaria Tropea, ${ }^{1}$ Silvia Conti, ${ }^{7}$ Utpal Das, ${ }^{5}$ Subhojit Roy, ${ }^{5,6}$ Maria Adelaide Pronzato, ${ }^{2}{ }^{-0}$ Ottavio Arancio, ${ }^{7}$ \\ (DErnesto Fedele, ${ }^{3,4}$ and Daniela Puzzo ${ }^{1}$ \\ ${ }^{1}$ Department of Biomedical and Biotechnological Sciences, Section of Physiology, University of Catania, 95123 Catania, Italy, ${ }^{2}$ Department of Experimental \\ Medicine, Section of General Pathology, School of Medical and Pharmaceutical Sciences, University of Genoa, 16132 Genoa, Italy, ${ }^{3}$ Department of \\ Pharmacy, Section of Pharmacology and Toxicology, School of Medical and Pharmaceutical Sciences, University of Genoa, 16148 Genoa, Italy, ${ }^{4}$ Center of \\ Excellence for Biomedical Research, University of Genoa, 16132 Genoa, Italy, ${ }^{5}$ Department of Pathology and Department of Neurosciences, University \\ of California, San Diego, La Jolla, California 92093, ${ }^{6}$ Department of Pathology and Department of Neuroscience, University of Wisconsin, Madison, \\ Wisconsin 53705, and ${ }^{7}$ Department of Pathology and Cell Biology \& The Taub Institute, Columbia University, New York, New York, 10032
}

High levels of amyloid- $\beta$ peptide $(\mathrm{A} \beta$ ) have been related to Alzheimer's disease pathogenesis. However, in the healthy brain, low physiologically relevant concentrations of $\mathrm{A} \beta$ are necessary for long-term potentiation (LTP) and memory. Because cGMP plays a key role in these processes, here we investigated whether the cyclic nucleotide cGMP influences A $\beta$ levels and function during LTP and memory. We demonstrate that the increase of cGMP levels by the phosphodiesterase- 5 inhibitors sildenafil and vardenafil induces a parallel release of $A \beta$ due to a change in the approximation of amyloid precursor protein (APP) and the $\beta$-site APP cleaving enzyme 1. Moreover, electrophysiological and behavioral studies performed on animals of both sexes showed that blocking $\mathrm{A} \beta$ function, by using anti-murine $\mathrm{A} \beta$ antibodies or APP knock-out mice, prevents the cGMP-dependent enhancement of LTP and memory. Our data suggest that cGMP positively regulates A $\beta$ levels in the healthy brain which, in turn, boosts synaptic plasticity and memory.

Key words: amyloid beta; APP; cGMP; long-term potentiation; memory; synaptic plasticity

\section{Significance Statement}

Amyloid- $\beta(\mathrm{A} \beta)$ is a key pathogenetic factor in Alzheimer's disease. However, low concentrations of endogenous $\mathrm{A} \beta$, mimicking levels of the peptide in the healthy brain, enhance hippocampal long-term potentiation (LTP) and memory. Because the second messenger cGMP exerts a central role in LTP mechanisms, here we studied whether cGMP affects A $\beta$ levels and function during LTP. We show that cGMP enhances A $\beta$ production by increasing the APP/BACE- 1 convergence in endolysosomal compartments. Moreover, the cGMP-induced enhancement of LTP and memory was disrupted by blockade of A $\beta$, suggesting that the physiological effect of the cyclic nucleotide on LTP and memory is dependent upon A $\beta$.

\section{Introduction}

Synaptic plasticity is a multifaceted property of the brain that dynamically modifies neuronal activity following adequate stim-

Received Nov. 22, 2016; revised June 1, 2017; accepted June 8, 2017.

Author contributions: A.P., R.R., M.A.P., O.A., E.F., and D.P. designed research; R.R., W.G., D.R., C.R., E.C., M.R.T., S.C., U.D., S.R., E.F., and D.P. performed research; R.R., W.G., M.R.T., E.F., and D.P. analyzed data; A.P., R.R., O.A., E.F., and D.P. wrote the paper.

This work was supported by the Alzheimer's Association (IIRG-09-134220 to D.P.), the University of Catania (Progetto di Ricerca d'Ateneo to A.P.), the University of Genoa (Progetto di Ricercad'Ateneo to E.F. and R.R.), and the National Institutes of Health (NSO49442/NS092045 to 0.A.)

The authors declare no competing financial interests.

*A.P. and R.R. contributed equally to this work.

Correspondence should be addressed to either of the following: Daniela Puzzo, Department of Biomedical and Biotechnological Sciences, Section of Physiology, University of Catania, Via S. Sofia 89, 95123 Catania, Italy, uli. Plastic changes have been related to learning and memory, defined as the ability of an organism to modify its behavior through experience and to retain this information over time. Molecular mechanisms underpinning synaptic plasticity and memory have been widely studied in the last decades and the scientific community has mostly focused on long-term potentiation (LTP), a form of long-lasting synaptic strengthening thought to be the electrophysiological correlate of memory. In this regard, it is well established that the second messengers cyclic adenosine

E-mail: danypuzzo@yahoo.it; or Ernesto Fedele, Department of Pharmacy, Section of Pharmacology and Toxicology, University of Genoa, Viale Cembrano 4, 16148 Genoa, Italy, E-mail: fedele@difar.unige.it. DOI:10.1523/JNEUROSCI.3607-16.2017

Copyright $\odot 2017$ the authors $\quad 0270-6474 / 17 / 376926-12 \$ 15.00 / 0$ 
monophosphate (cAMP) and cyclic guanosine monophosphate (cGMP) play a crucial role in LTP signal transduction mechanisms, and are involved in both memory induction and maintenance/consolidation processes (Bernabeu et al., 1996; Son et al., 1998; Lu et al., 1999; Bollen et al., 2014). As a matter of fact, several studies have focused on the potential use of phosphodiesterase inhibitors (PDE-Is) for their ability to enhance cyclic nucleotide levels and memory in healthy conditions and in neurological disorders characterized by synaptic and memory deficits, such as Alzheimer's disease (AD; Prickaerts et al., 2002; Gong et al., 2004; Puzzo et al., 2005, 2009, 2014, Rutten et al., 2005, 2008; Shim et al., 2011; Orejana et al., 2012; Palmeri et al., 2013; Sakurai et al., 2013). This is consistent with the hypothesis that downregulation of cyclic nucleotide levels during aging and neurodegenerative disorders might be related to cognitive decline (Yamamoto et al., 2000; Teich et al., 2015). High levels of amyloid- $\beta(\mathrm{A} \beta)$ downregulate both the cAMP and cGMP pathways and, on the other hand, the increase of cyclic nucleotides by PDE-Is is capable of modifying $\mathrm{A} \beta$ levels (Baltrons et al., 2002, 2004; Vitolo et al., 2002; Gong et al., 2004; Puzzo et al., 2005, 2009, 2014; Cheng et al., 2010; Zhang et al., 2013; Lee et al., 2014). Interestingly, upregulation of cGMP levels by PDE5-Is decreased $\mathrm{A} \beta$ load in transgenic models of AD (Puzzo et al., 2009; Zhang et al., 2013; Zhu et al., 2015) and in models of physiological aging (Puzzo et al., 2014), whereas it induced a slight increase of $A \beta$ in young healthy mice (Puzzo et al., 2014). This dichotomy might be interpreted in light of the peculiar double-role of $A \beta$, which is present at high concentrations in $\mathrm{AD}$ brains where it exerts a synaptotoxic effect, and at low picomolar concentrations in healthy brains where, on the contrary, it mediates physiological mechanisms underlying learning and memory (for review, see Puzzo et al., 2015; Ricciarelli and Fedele, 2017). Indeed, administration of human $\mathrm{A} \beta$ at low picomolar concentrations, resembling its physiological content in the brain (Puzzo et al., 2008, 2011), has been found to enhance LTP and memory in healthy mice (Puzzo et al., 2008, 2012; Morley et al., 2010; Lawrence et al., 2014). Furthermore, $A \beta$ is physiologically released during neuronal activity (Kamenetz et al., 2003; Cirrito et al., 2005) and it is needed for normal synaptic plasticity and memory (Puzzo et al., 2011). Considering the key role of both cGMP and A $\beta$ in LTP and memory, and their reciprocal relationships, here we sought to examine how they interact in physiological conditions. Our findings revealed that cGMP causes an increase in $\mathrm{A} \beta$ levels by modifying $\beta$-site APP cleaving enzyme-1 (BACE-1) and amyloid precursor protein (APP) approximation. Furthermore, blocking the endogenous $A \beta$ function prevented the well known cGMP-dependent enhancement of LTP and memory. These results suggest a possible novel mechanism according to which cGMP acts upstream of $A \beta$ by stimulating its production. $\mathrm{A} \beta$, in turn, is responsible for the enhancement of LTP and memory.

\section{Materials and Methods}

Ethics statement. All the experimental procedures were in accordance with the European and Italian guidelines for the care of laboratory animals and the Italian legislation on animal experimentation, and were approved by the institutional ethical committee. All efforts were made to minimize animal suffering and to use the minimum number of animals necessary to produce reliable results.

Drugs preparation and administration. Vardenafil and sildenafil were obtained from Sigma-Aldrich. ODQ was purchased from Tocris Bioscience. All chemicals were first dissolved in DMSO and then diluted in the appropriate medium for N2a cells and hippocampal slices, in ACSF for electrophysiological experiments, and in saline solution $(\mathrm{NaCl} 0.9 \%)$ for behavioral experiments, immediately before use. Final concentrations were chosen based on previous studies (Prickaerts et al., 2002; Bollen et al., 2014). For electrophysiological studies, we used exogenous human synthetic $\mathrm{A} \beta_{42}$ to perform rescue experiments. $\mathrm{A} \beta_{42}$ (American Peptide) was prepared as previously described (Puzzo et al., 2008). Briefly, the lyophilized peptide was suspended in 100\% 1,1,1,3,3,3-hexafluoro-2propanol (HFIP) (Sigma-Aldrich) to $1 \mathrm{~mm}$. HFIP was allowed to evaporate, and the resulting clear peptide film was stored at $-80^{\circ} \mathrm{C}$. The film was added to DMSO (Sigma-Aldrich) and sonicated for $10 \mathrm{~min}$. $\mathrm{A} \beta_{42^{-}}$ DMSO aliquots were prepared and stored at $-20^{\circ} \mathrm{C}$. Twenty-four hours before the use, one aliquot was diluted to the final concentration in artificial CSF (ACSF; for the composition see below) and incubated at $4^{\circ} \mathrm{C}$ for $24 \mathrm{~h}$ to allow oligomerization. As in our previous works (Puzzo et al., 2008, 2011, 2012), we have chosen to use this synthetic A $\beta$ preparation, containing both monomers and oligomers, to reproduce the physiological brain environment where a certain degree of oligomerization is likely to occur (Puzzo et al., 2008). Concentrations of $A \beta_{42}$ were calculated based on the molecular weight of its monomeric peptide. Moreover, preliminary experiments ensured that scramble $\mathrm{A} \beta_{42}$ (AnaSpec) did not exert any effect, as previously demonstrated (Puzzo et al., 2008).

$A \beta_{42}$ evaluation in cell cultures and hippocampal slices. Mouse N2a cells were grown in 50\% DMEM, 50\% OptiMEM, with $0.1 \mathrm{~mm}$ nonessential amino acids, $1 \%$ penicillin-streptomycin mixture, and 5\% fetal bovine serum. They were treated for 1 or $5 \mathrm{~h}$ with vehicle or drugs, as indicated. Transverse rat hippocampal slices $(250 \mu \mathrm{m})$ were obtained using a McIlwain tissue chopper. Slices were incubated for $1 \mathrm{~h}$ at $37^{\circ} \mathrm{C}$ into $2 \mathrm{ml}$ of a physiological solution continuously aerated with $95 \% \mathrm{O}_{2}$ and $5 \% \mathrm{CO}_{2}$ in the presence of PDE5-Is as indicated. $\mathrm{A} \beta_{42}$ released into supernatant media from cultured cells and hippocampal slices was measured by $\mathrm{A} \beta_{1-42}$ ELISA (Wako Chemicals GmbH).

cGMP enzymatic immunoassay. Quantification of intracellular cGMP was performed with DetectX Direct Cyclic GMP Enzyme Immunoassay Kit (Arbor Assay), following the manufacturer's protocol. cGMP levels were calculated according to the standard curves prepared on the same enzymatic immunoassay (EIA) plates.

Immunoblot analysis. APP protein expression was evaluated in N2a cells and hippocampal slices. Cells were processed for total protein extraction as previously reported (Canepa et al., 2013). Hippocampal slices were homogenized in $0.6 \mathrm{ml}$ of ice-cold buffer containing $1 \%$ complete protease inhibitor, $1 \%$ Triton X-100, $25 \mathrm{~mm}$ Tris $\mathrm{HCl}, 25 \mathrm{~mm} \mathrm{NaF}, 1 \mathrm{~mm}$ EDTA, $0.5 \mathrm{~mm}$ EGTA, sonicated for $30 \mathrm{~s}$, and centrifuged at $10,000 \times g$ for $10 \mathrm{~min}$ at $4^{\circ} \mathrm{C}$. The supernatant was centrifuged a second time at $10,000 \times g$ for $10 \mathrm{~min}$ and then used for APP immunoblot assay, performed according to standard methods. As primary antibodies, we used a monoclonal mouse anti-human APP $(22 \mathrm{C} 11,1 \mu \mathrm{g} / \mathrm{ml}$; Millipore Bioscience Research Reagents) and a monoclonal mouse anti-human $\beta$-actin (clone AC-15, 1:10,000; Sigma-Aldrich). Anti-mouse secondary antibodies were coupled to horseradish peroxidase (GE Healthcare). Proteins were visualized with an enzyme-linked chemiluminescence detection kit according to the manufacturer's instructions (GE Healthcare). Chemiluminescence was monitored by exposure to film and the signals were analyzed under non-saturating condition with an image densitometer (Bio-Rad).

BACE activity. The activity of BACE in N2a cells was determined using the $\beta$-Secretase Activity Fluorimetric Assay kit from BioVision, according to the manufacturer's protocol. The method is based on the BACEdependent cleavage of a secretase-specific peptide conjugated to the fluorescent reporter molecules EDANS and DABCYL, which results in the release of a fluorescent signal that can be detected on a fluorescence microplate reader (excitation at $355 \mathrm{~nm} /$ emission at $510 \mathrm{~nm}$ ). The level of secretase enzymatic activity is proportional to the fluorometric reaction.

APP-BACE1 interaction assay. Primary hippocampal neurons were cultured from postnatal day $(\mathrm{P}) 0-\mathrm{P} 1 \mathrm{CD} 1$ mice and transiently transfected with Lipofectamine 2000 as described previously (Tang et al., 2012). Briefly, neurons were dissociated and plated on poly-D-lysinecoated glass-bottom dishes from Mattek at a density of 50,000 cells $/ \mathrm{cm}^{2}$, and maintained in neurobasal/B27 medium with $5 \% \mathrm{CO}_{2}$ and $80 \%$ humidity. On DIV10, neurons were transfected with APP:VN, BACE1:VC, 
and Lamp1:mCherry $(1.2 \mu \mathrm{g} / \mathrm{ml})$ DNA, as previously described (Das et al., 2016). After 6 h, neurons were incubated with DMSO or vardenafil for $16 \mathrm{~h}$ and fixed in $4 \%$ PFA. Images were acquired using an Olympus IX81 inverted epifluorescence microscope. $Z$-stack images were captured using a $100 \times$ objective (imaging parameters: $0.339 \mu \mathrm{m} z$-step, $500 \mathrm{~ms}$ exposure and $1 \times 1$ binning). Captured images were deconvolved (Huygens, Scientific Volume Imaging B.V.) and subjected to a maximum intensity projection.

Animals. We used 3- to 4-month-old C57BL/6J wild-type (WT) and APP KO (B6.129S7-Apptm1Dbo/J) mice from a colony kept in the animal facility of the University of Catania, and adult Sprague-Dawley rats from a colony kept in the animal facility of the University of Genoa. The animals were maintained on a $12 \mathrm{~h}$ light/dark cycle (lights on at 6:00 A.M.) in temperature and humidity-controlled rooms; food and water were available ad libitum.

Electrophysiology. Electrophysiological recordings were performed as previously described (Bollen et al., 2014; Ricciarelli et al., 2014) on male animals. Briefly, transverse hippocampal slices $(400 \mu \mathrm{m})$ were cut and transferred to a recording chamber where they were maintained at $29^{\circ} \mathrm{C}$ and perfused with ACSF (in mM: $124.0 \mathrm{NaCl}, 4.4 \mathrm{KCl}, 1.0 \mathrm{Na}_{2} \mathrm{HPO}_{4}, 25.0$ $\mathrm{NaHCO}_{3}, 2.0 \mathrm{CaCl}_{2}, 2.0 \mathrm{MgCl}_{2}$; flow rate $2 \mathrm{ml} / \mathrm{min}$ ) continuously bubbled with $95 \% \mathrm{O}_{2}$ and $5 \% \mathrm{CO}_{2}$. Field extracellular recordings were performed by stimulating the Schaeffer collateral fibers through a bipolar tungsten electrode and recording in CA1 stratum radiatum with a glass pipette filled with ACSF. A 15 min baseline was recorded every minute at an intensity that evoked a response $\sim 35 \%$ of the maximum evoked response. LTP was induced through either a weak or a strong tetanus. The weak tetanus consisted of a theta burst stimulation including bursts of four $1 \mathrm{~ms}$ pulses at $100 \mathrm{~Hz}$, with the bursts repeated at $5 \mathrm{~Hz}$ for 10 times and an intensity of stimulation for the individual pulses equal to $\sim 35 \%$ of the maximum evoked response. The strong tetanus was similar to the weak tetanus. However, instead of providing only one theta burst stimulation, three trains of theta bursts were administered with an intertrain interval of $15 \mathrm{~s}$. Responses were recorded for $3 \mathrm{~h}$ after tetanization and measured as field EPSP slope expressed as percentage of baseline. The results were expressed as mean \pm SEM.

Object recognition test. The object recognition test (ORT) was performed as previously described (Bollen et al., 2014) in sex-balanced WT mice. To allow mice to familiarize with the environment and the injection, mice underwent $3 \mathrm{~d}$ of handling, observation by the experimenter, and habituation to the arena and the injection. Animals were put in the arena (white plastic box $50 \times 35 \times 15 \mathrm{~cm}$ ) and exposed to two different objects (changing from day to day). After 5 min of habituation, they received intraperitoneal injection of saline solution and were put back in their home cage. On the fourth day mice underwent the ORT training session (T1). Animals were put in the arena containing two identical objects (glass vases) placed in the central part of the box, equally distant from the perimeter. The animal was given $3 \mathrm{~min}$ to explore the environment and objects. Immediately after, $\mathrm{T} 1$ animals received an intraperitoneal injection of vardenafil ( $1 \mathrm{mg} / \mathrm{kg})$. Twenty-four hours after T1, the mouse was put back in the arena to perform the test (T2). In this second trial, lasting $3 \mathrm{~min}$, one familiar object (used in T1) was replaced by a novel object (ceramic cup). The time spent exploring the objects was scored using a personal computer by an experimenter who was blinded to the conditions tested. We opted for a delay interval of $24 \mathrm{~h}$, at which under normal, nontreated circumstances, no discrimination between the objects occurs (natural forgetting), which allows for an improvement of long-term memory performance following drug treatment. Animal exploration, defined as the mouse pointing its nose toward the object from a distance not $>2 \mathrm{~cm}$, was evaluated in T2 to analyze: (1) time of exploration of each object and total time of exploration of the two objects expressed as percentage exploration of the novel and percentage exploration of the familiar object, (2) discrimination (D) index calculated as "exploration of novel object minus exploration of familiar object/total exploration time", (3) latency to first approach to novel object, and (4) total exploration time.

Statistical analyses. All data were expressed as mean \pm SEM. Statistical analysis was performed by using Systat software. Normal distribution was prior evaluated by Kolmogorov-Smirnov test $(p>0.05)$. We used unpaired $t$ test, one-way and two-way ANOVA with Bonferroni post hoc. Pearson's correlation was used to correlate $A \beta_{42}$ and cGMP levels. For LTP we used ANOVA with repeated measures comparing $180 \mathrm{~min}$ of recording after tetanus. For ORT we used one-way ANOVA with Bonferroni post hoc for comparisons among groups, paired $t$ test to compare exploration of the novel versus the familiar object in the same mouse, one-sample $t$ test to compare $\mathrm{D}$ with zero. The level of significance was set at $p<0.05$.

\section{Results}

\section{The increase of cGMP increases A $\beta$ levels}

We first investigated whether cGMP elevation affects $\mathrm{A} \beta$ secretion in N2a cells. N2a cells were treated with $100 \mu \mathrm{M}$ sildenafil, vardenafil (Shim et al., 2011), or vehicle for $1 \mathrm{~h}$. The intracellular content of cGMP was measured by a cGMP-specific EIA assay, whereas $\mathrm{A} \beta_{42}$ levels in the conditioned medium were measured by ELISA. We confirmed that treatment with the PDE5-Is induced an increase of intracellular cGMP content in N2a cells compared with vehicle $\left(F_{(2,6)}=12.746, p=0.007\right.$; Fig. $\left.1 A\right)$. This was particularly evident for vardenafil, which was able to determine a $23.36 \pm 5.75$-fold induction in cGMP content $\left(t_{(4)}=\right.$ $3.883, p=0.018)$. The $c$ GMP increase stimulated $\mathrm{A} \beta_{42}$ secretion in N2a cells (1.4-fold increase, $t_{(4)}=3.933, p=0.017$ for sildenafil and twofold increase, $t_{(4)}=5.678, p=0.005$ for vardenafil; Figure $1 A$ ). Thus, the increase in cGMP content paralleled the increase of $\mathrm{A} \beta_{42}$ levels $\left(F_{(2,6)}=18.936, p=0.003\right)$. Pearson's correlation coefficient between the PDE5-I-induced cGMP and $\mathrm{A} \beta_{42}$ was equal to 0.97 , confirming a very strong relationship between the two events.

Next, we validated findings from N2a cells using a different system, the hippocampus, a region of the brain with remarkable plastic characteristics of the kind that are required for learning and memory. Rat hippocampal slices were incubated for $1 \mathrm{~h}$ with $100 \mu \mathrm{M}$ sildenafil or vardenafil and then the conditioned medium was analyzed for $\mathrm{A} \beta_{42}$ content. A significant difference was found in slices treated with PDE5-Is with respect to controls $\left(F_{(2,6)}=\right.$ $57.575, p<0.0001)$, confirming the increase of $\mathrm{A} \beta_{42}$ levels after treatment with sildenafil $\left(t_{(4)}=4.548, p=0.010\right.$; Fig. $\left.1 B\right)$ or vardenafil $\left(t_{(4)}=13.462, p<0.0001\right.$; Fig. $1 B$ ) observed in $\mathrm{N} 2 \mathrm{a}$ cells. Together, these findings indicate that cGMP increase induces $\mathrm{A} \beta_{42}$ secretion in N2a cells and hippocampal slices, with vardenafil being more effective than sildenafil in determining this effect (vardenafil vs sildenafil in N2a cells: $t_{(10)}=5.136, p<$ 0.0001; in slices: $t_{(4)}=5.241, p=0.006$ ).

These results prompted us to perform a dose-response curve to evaluate the minimum dose of vardenafil capable of stimulating $\mathrm{A} \beta_{42}$ secretion. $\mathrm{N} 2 \mathrm{a}$ cells were treated for $1 \mathrm{~h}$ with vardenafil at different concentrations ranging from 1 to $100 \mu \mathrm{M}$. The increase of $\mathrm{A} \beta_{42}$ levels was significant after a treatment with vardenafil at $100 \mu \mathrm{M}$, whereas no differences were detected at 1 or 10 $\mu \mathrm{M}$ (ANOVA for the dose-response curve: $F_{(3,14)}=58.153, p<$ 0.0001 ; Bonferroni's $p<0.001$ for vardenafil $100 \mu \mathrm{M}$ vs other conditions; Fig. 1C). A prolonged exposure to vardenafil revealed a time- and concentration-dependent increase of $\mathrm{A} \beta_{42}$ levels (two-way ANOVA for time and treatment: $F_{(3,22)}=10.461, p<$ $0.0001)$. After $5 \mathrm{~h}$ of exposure to the drug there was a significant difference from control $\left(F_{(3,8)}=98.320, p<0.0001\right)$ with a concentration of both $10 \mu \mathrm{M}$ (Bonferroni's $p=0.005$ ) and $100 \mu \mathrm{M}$ (Bonferroni's $p<0.0001$; Fig. $1 C$ ).

Because the intracellular cGMP concentration reflects a fine balance between cyclic nucleotide production by soluble guanylyl cyclase (sGC) and degradation by PDEs, we further investigated 
A
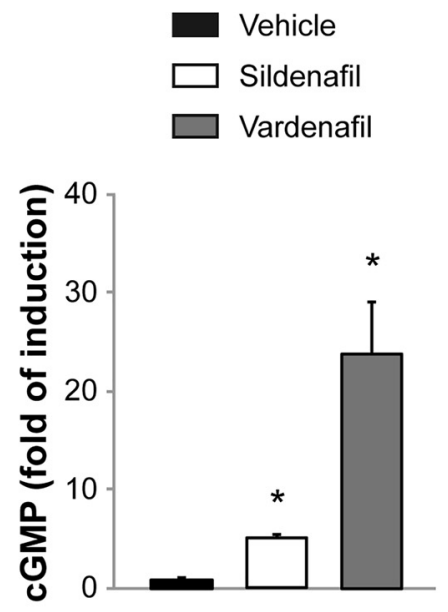

C

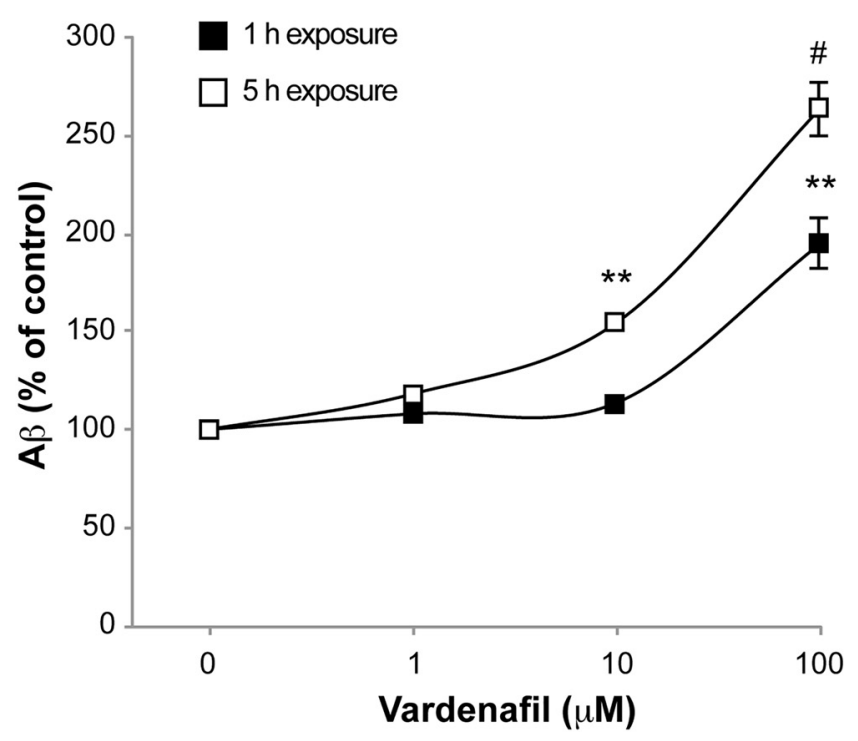

B

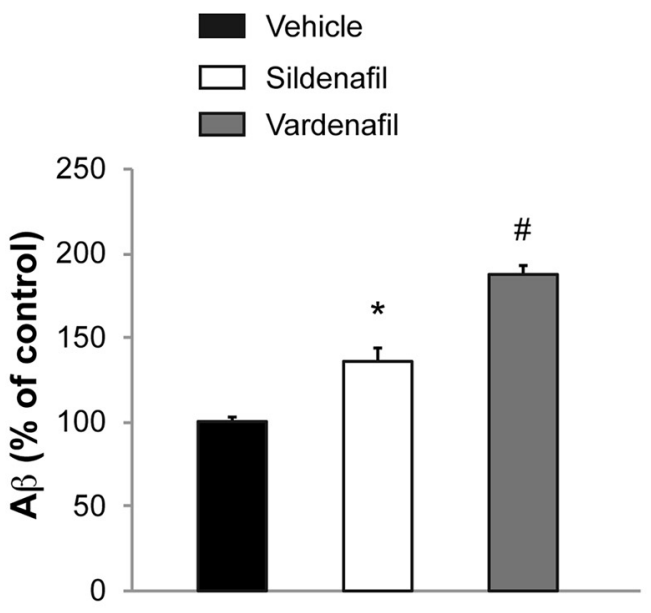

D
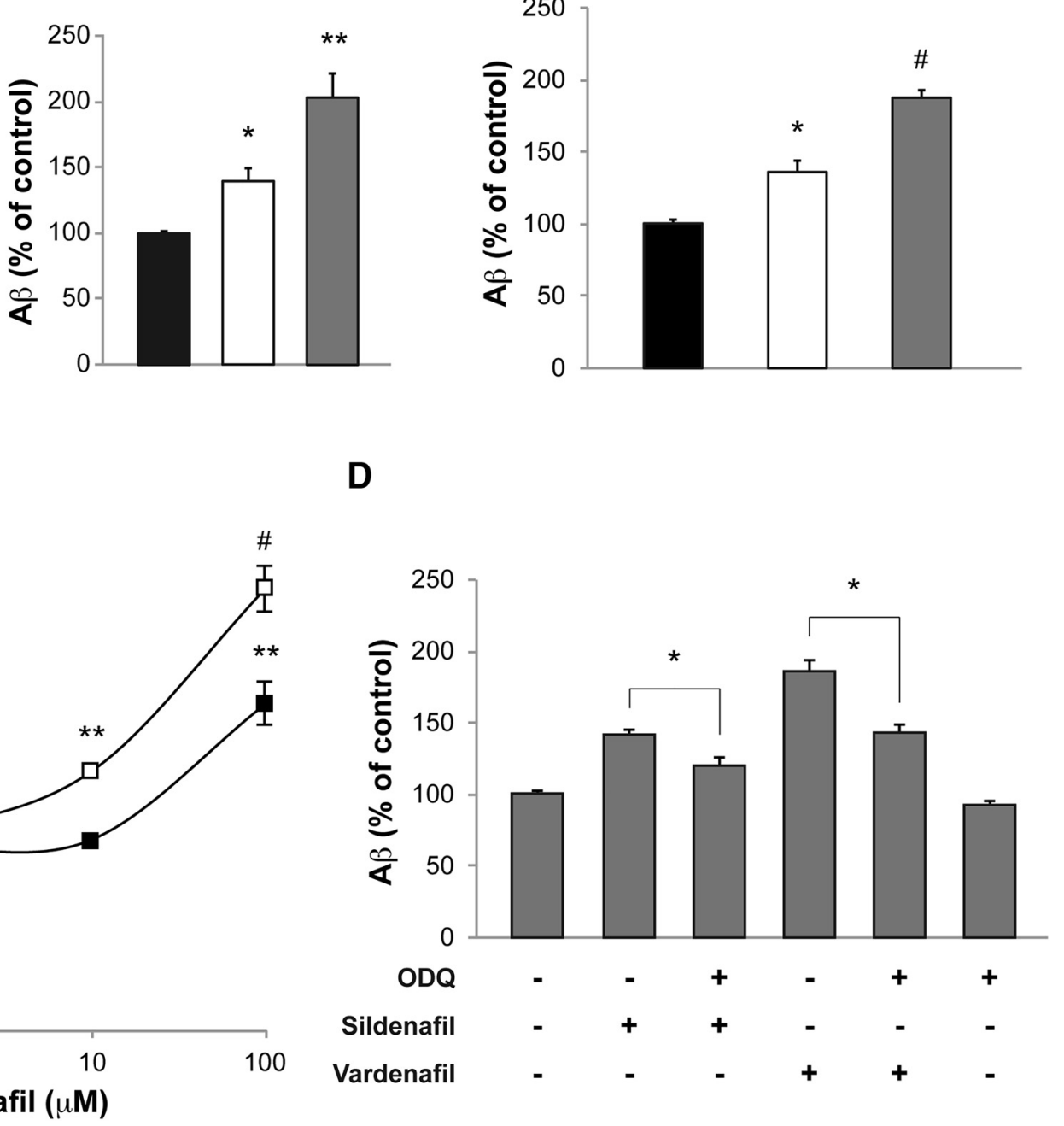

Figure 1. GGMP increase stimulates $A \beta$ secretion. $A$, Vardenafil and sildenafil stimulate $A \beta$ secretion in N2a cells. A treatment with $100 \mu m$ sildenafil or vardenafil for $1 \mathrm{~h}$ increases intracellular cGMP levels compared with vehicle (fold-induction in cGMP content: sildenafil $=5.17 \pm 0.34 ;$ vardenafil $=23.36 \pm 5.75 ; p<0.05$ ). ELISA measurement of $A \beta_{42}$ in conditioned media reveals that the increase in cGMP levels induces a parallel increase of $A \beta$ secretion ( $A \beta$ levels percentage of control: sildenafil $=139 \pm 9.84 \%, p<0.05$; vardenafil $=202 \pm 17.92 \%$ of control, $p<$ 0.005). $B, A$ treatment with vardenafil and sildenafil increases $A \beta_{42}$ levels in rat hippocampal slices. In particular, sildenafil induces an increase equal to $136 \pm 7.57 \%$ of control and vardenafil an increase equal to $187.3 \pm 7.75 \%$ of control. C, Dose-response curve for the effect of different concentrations of vardenafil on $\mathrm{A} \beta_{42}$ levels after $1 \mathrm{~h}$ ( $1 \mu \mathrm{m}: 108.5 \pm 2.5 \%$ of control; $10 \mu \mathrm{m}$ : $113.5 \pm$ $0.5 \%$ of control; $100 \mu \mathrm{m}: 194.33 \pm 12.90 \%$ of control) or $5 \mathrm{~h}$ ( $1 \mu \mathrm{m}: 118.33 \pm 3.17 \%$ of control; $10 \mu \mathrm{m}: 154.33 \pm 2.84 \%$ of control; $100 \mu \mathrm{m}: 262.66 \pm 13.86 \%$ of control). ${ }^{*} p<0.05$; ${ }^{* *} p<0.005$; $\# p<0.0001$. D, The guanylyl cyclase inhibitor ODQ reduces $A \beta$ secretion induced by sildenafil (120.3 $\pm 6.33 \%$ vs $142.33 \pm 2.40$ of control) and vardenafil (145.33 $\pm 4.63 \%$ vs $186.26 \pm 7.28$ of control), but does not change $A \beta_{42}$ basal levels $(93.9 \pm 3.59 \%$ of control). Data are mean \pm SEM.

the involvement of cGMP on $\mathrm{A} \beta_{42}$ secretion in $\mathrm{N} 2 \mathrm{a}$ cells treated with the sGCinhibitor $[1 \mathrm{H}-[1,2,4]$ oxadiazolo-[4,3-a] quinoxalin1-one] (ODQ). As expected, the increase of $\mathrm{A} \beta_{42}$ levels induced by sildenafil and vardenafil was significantly reduced by ODQ pretreatment $(50 \mu \mathrm{M})\left(t_{(4)}=3.248, p=0.031\right.$ compared with sildenafil; $t_{(4)}=4.740, p=0.009$ compared with vardenafil; Figure $1 D$ ) which, however, did not alter, per se, the $\mathrm{A} \beta_{42}$ basal levels $\left(t_{(6)}=1.447, p=0.198\right.$; Fig. $\left.1 D\right)$.

Thus, when cGMP production was inhibited by ODQ, neither vardenafil nor sildenafil were capable of increasing $\mathrm{A} \beta$ levels, confirming a direct dependency between cGMP and A $\beta$ production.

\section{cGMP does not modify APP expression}

Because $A \beta$ is produced by APP cleavage (O'Brien and Wong, 2011), we examined whether the increase of cGMP might affect APP expression. N2a cells were treated with vardenafil and then processed for total protein extraction followed by immunoblot analysis performed with an antibody directed against the $\mathrm{N}$-terminus of APP (22C11). Vardenafil did not modify APP fulllength expression at different concentrations $\left(1-100 \mu \mathrm{M} ; F_{(3,8)}=\right.$ $1.401, p=0.312)$ and time-exposures $\left(1-5 \mathrm{~h} ; F_{(3,8)}=1.472, p=\right.$ 0.294; Fig. $2 A, B$ ). We also evaluated APP full-length expression in hippocampal slices, but no changes were detected after treatment with vardenafil or sildenafil $\left(F_{(3,8)}=2.562, p=0.157\right.$; Fig. 
A

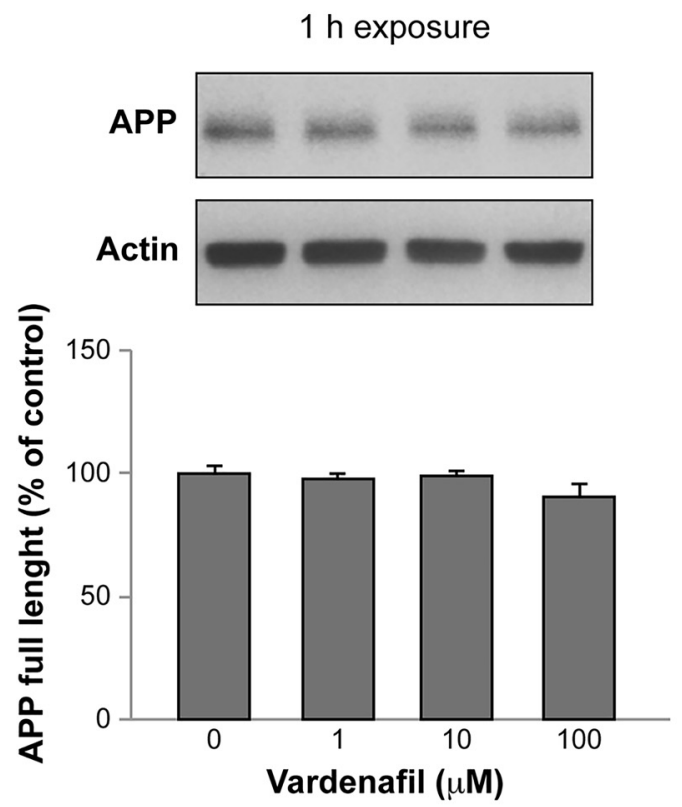

C

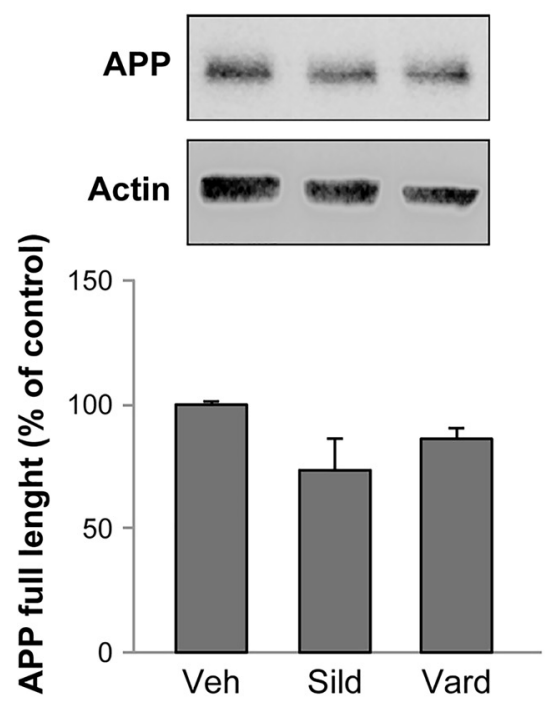

B

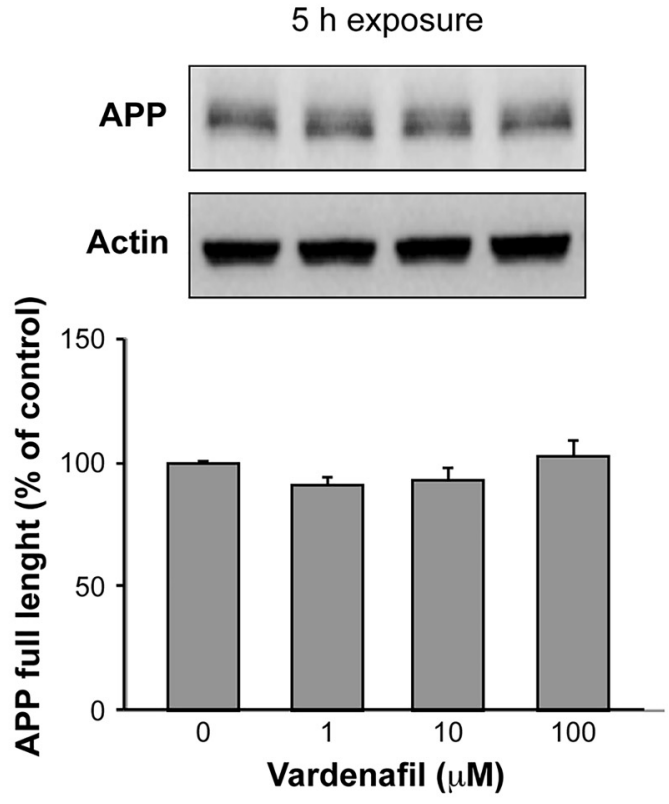

D

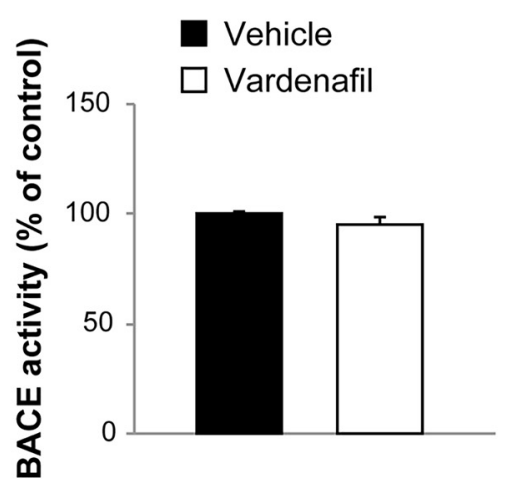

Figure 2. CGMP increase does not modify APP expression. $A, B, A$ treatment with vardenafil at different concentrations ranging from 1 to $100 \mu M$ does not modify APP full-length expression in N2a cells neither after $1 \mathrm{~h}(\boldsymbol{A})$ nor after $5 \mathrm{~h}(\boldsymbol{B})$ exposure. $\boldsymbol{C}$, A treatment with $100 \mu \mathrm{m}$ sildenafil or vardenafil does not modify APP full-length expression in hippocampal slices. Top, Immunoblots; bottom, results of the relative densitometric scan. $D$, The proteolytic activity of BACE- 1 on a secretase-specific exogenous substrate is not modified by treatment of N2a cells with $100 \mu m$ vardenafil. Data are mean \pm SEM.

$2 C)$. Thus, the cGMP-induced increase of $\mathrm{A} \beta$ was not due to an increase of full-length APP.

cGMP stimulates $\mathrm{A} \beta$ production by increasing APP/BACE-1 convergence in endolysosomal compartments

Considering that BACE- 1 cleavage of APP is a prerequisite for A $\beta$ formation, we evaluated the effect of vardenafil on the enzymatic activity of BACE-1. To this end, we tested the proteolytic activity of BACE-1, extracted from N2a cells treated with $100 \mu \mathrm{M}$ vardenafil, on a secretase-specific substrate that releases fluorescence after its cleavage. Under these experimental conditions, the activity of BACE-1 on the exogenous synthetic substrate was unmodified $\left(t_{(10)}=1.365, p=0.199\right.$; Fig. $\left.2 D\right)$.
Next, we examined whether cGMP affects APP-BACE- 1 approximation by direct visualization of the substrate-enzyme interaction in cells. Toward this, we used the Optical Convergence of APP and BACE-1 (OptiCAB) assay (Das et al., 2016), based on the bimolecular fluorescence complementation of Venus protein fragments (Kerppola, 2006). As described in Figure 3A, APP was tagged to the N-terminal fragment of the Venus protein (VN) and BACE-1 was tagged to the complementary C-terminal fragment of Venus (VC). The principle of this assay is that interaction between APP:VN and BACE-1:VC fragments reconstitutes the Venus protein, making it fluorescent (Das et al., 2016).

It was recently shown that the vast majority of APP and BACE-1 interactions take place in the recycling endosomes in the 
A
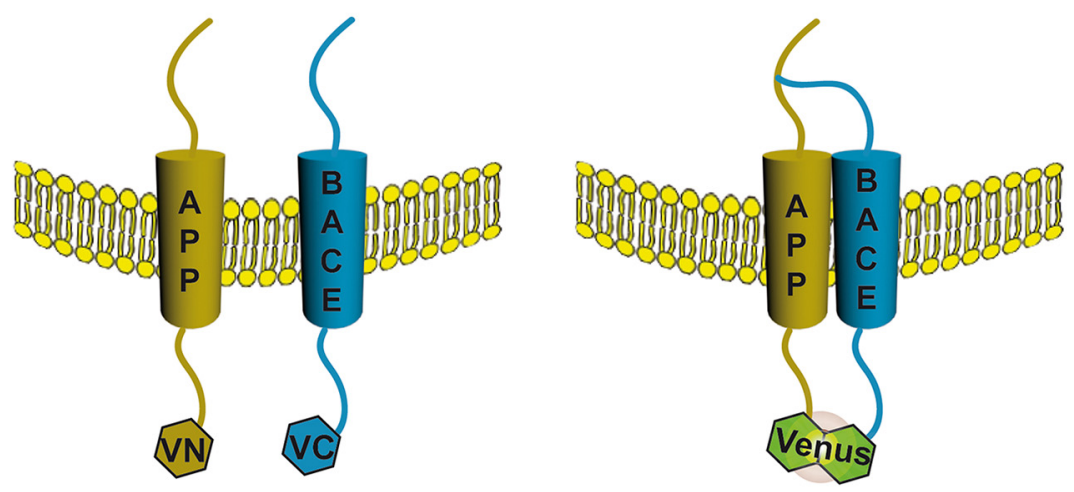

B
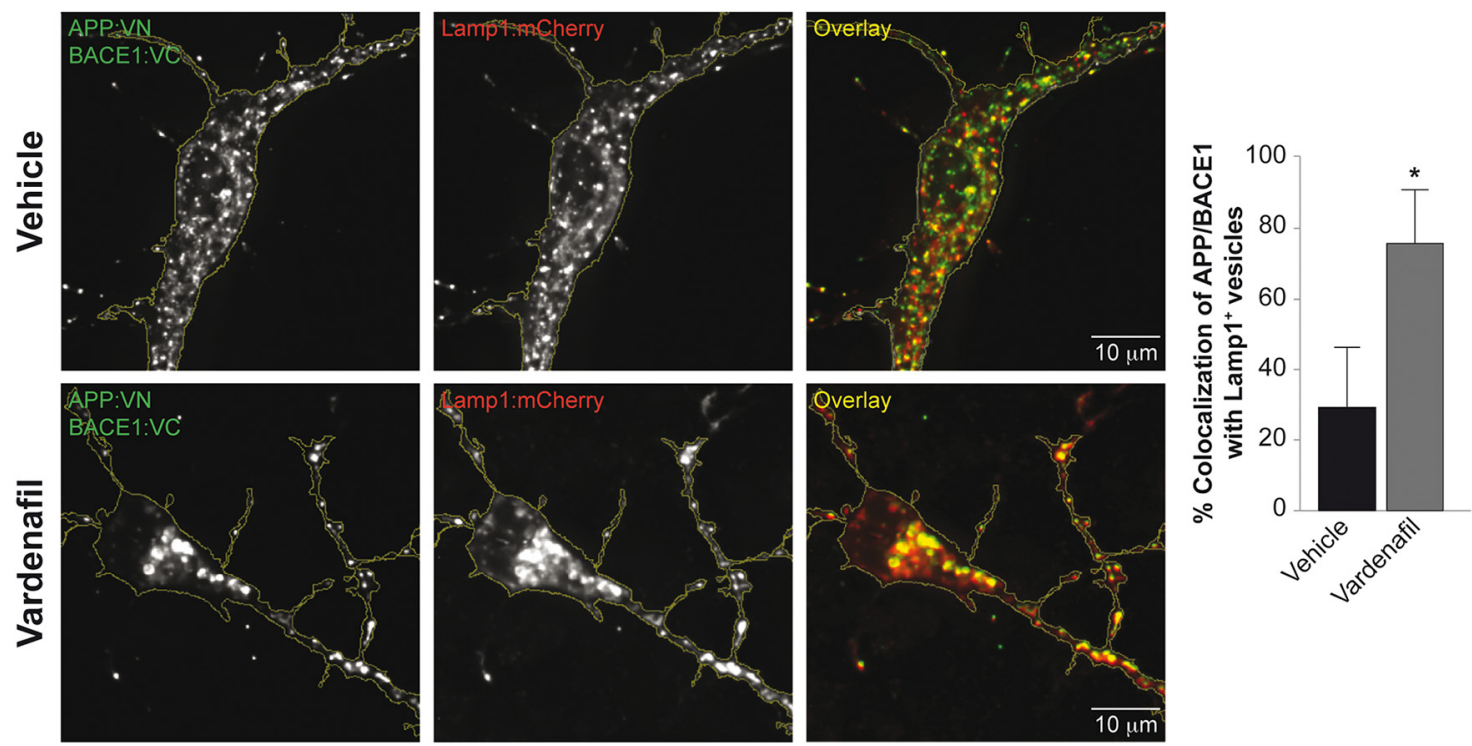

Figure 3. CGMP induces APP and BACE- 1 interaction in the late endosome/lysosomes. $A$, Graphical representation of OptiCAB assay used to detect APP-BACE-1 interactions. APP and BACE-1 are respectively tagged with the VN and the VC fragment of Venus protein. When APP interacts with BACE-1 Venus fluorescence is reconstituted (Venus fluorescence, right). $\boldsymbol{B}$, Fluorescence of cultured neurons expressing APP:VN, BACE-1:VC, Lamp1:mCherry, and treated with $100 \mu \mathrm{m}$ vardenafil or vehicle control for $16 \mathrm{~h}$. Note the increase $(78.27 \pm 8.97 \%)$ in the colocalization of Venus-positive puncta indicating APP/BACE-1 interaction with Lamp1, a late endosome/lysosome marker, compared with DMSO (vehicle)-treated control set (28.82 $\pm 10.12 \%) . n=10-12$ neurons for each condition. ${ }^{*} p<0.05$. Data are mean \pm SEM.

somatodendritic compartments of primary cultured neurons (Das et al., 2016). Interestingly, after cotransfecting the neurons with APP:VN, BACE-1:VC and Lamp1:mCherry, a late endosome/lysosome marker, we observed a significant increase in the colocalization of Venus puncta with the Lamp1-positive organelles in the presence of $100 \mu \mathrm{M}$ vardenafil $\left(t_{(4)}=3.396 ; p=0.027\right.$; Fig. 3B).

\section{$A \boldsymbol{\beta}$ is required for $\mathrm{CGMP}$-induced late-LTP}

cGMP signaling has been demonstrated to play a pivotal role in LTP and synaptic plasticity (Arancio et al., 1995; Son et al., 1998; Lu et al., 1999). A tetanic stimulation of presynaptic fibers results in a transient increase in cGMP (Monfort et al., 2002), which is responsible for the enhancement of synaptic plasticity. Drugs enhancing cGMP levels are able to convert short-lasting early phase LTP (e-LTP) into a long-lasting form of LTP, called lateLTP (1-LTP) (Bollen et al., 2014). We therefore confirmed that the increase of cGMP levels by PDE5 inhibition was capable of converting e-LTP into l-LTP when Schaffer collateral fibers of hippocampal slices are stimulated in vitro with a weak tetanic stimulation including a theta burst stimulation consisting of four-pulse bursts at $100 \mathrm{~Hz}$, with the bursts repeated at $5 \mathrm{~Hz}$ for 10 times and an intensity of stimulation for the individual pulses equal to $\sim 35 \%$ of the maximum evoked response (Puzzo et al., 2009; Bollen et al., 2014; Ricciarelli et al., 2014).

Slices were perfused with 50 nm sildenafil (Puzzo et al., 2009) or $10 \mathrm{~nm}$ vardenafil (Bollen et al., 2014) for $10 \mathrm{~min}$ before tetanus. Both sildenafil and vardenafil produced a robust l-LTP lasting at least $3 \mathrm{~h}$ (ANOVA for repeated measures of the post-tetanic time points: sildenafil: $F_{(1,12)}=40.218, p<0.0001$; vardenafil: $F_{(1,12)}=$ $32.115, p<0.0001$, both compared with vehicle + weak tetanus; Figure $4 A$ ), whereas vehicle-treated slices showed lower amounts of LTP fading at $\sim 1 \mathrm{~h}$. The PDE5-I-induced LTP was similar to LTP induced through a strong tetanic stimulation in which, instead of providing only one theta burst stimulation, we administered three trains of theta bursts with an intertrain interval of $15 \mathrm{~s}$ (sildenafil: $F_{(1,10)}=3.070, p=0.110$; vardenafil: $F_{(1,12)}=0.181, p=$ 0.678 , both compared with vehicle + strong tetanus; Figure $4 A$ ).

Because a relatively high concentration of vardenafil $(100 \mu \mathrm{M})$ was applied to slices for $1 \mathrm{~h}$ to produce a significant increase in $\mathrm{A} \beta$ 

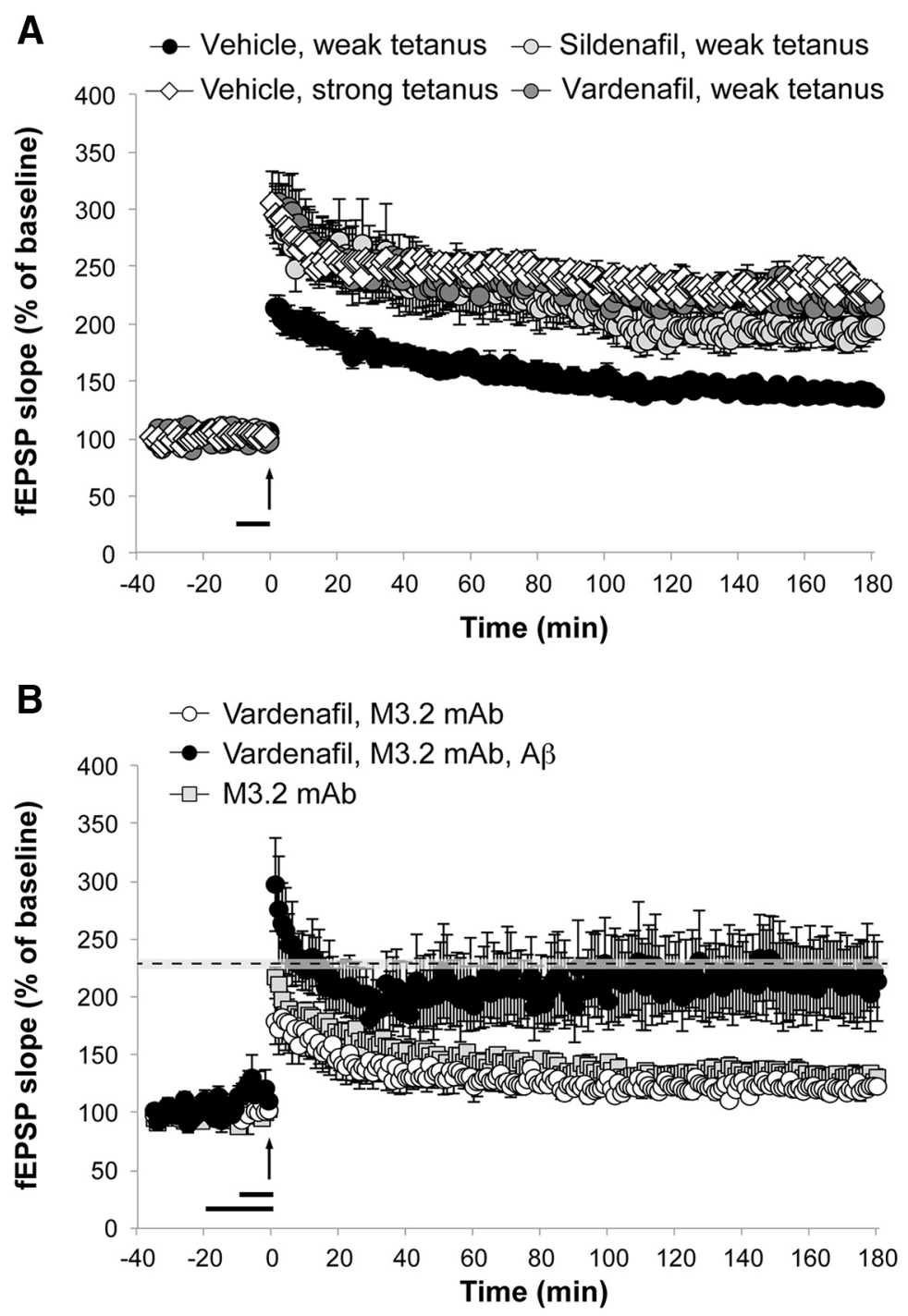

C

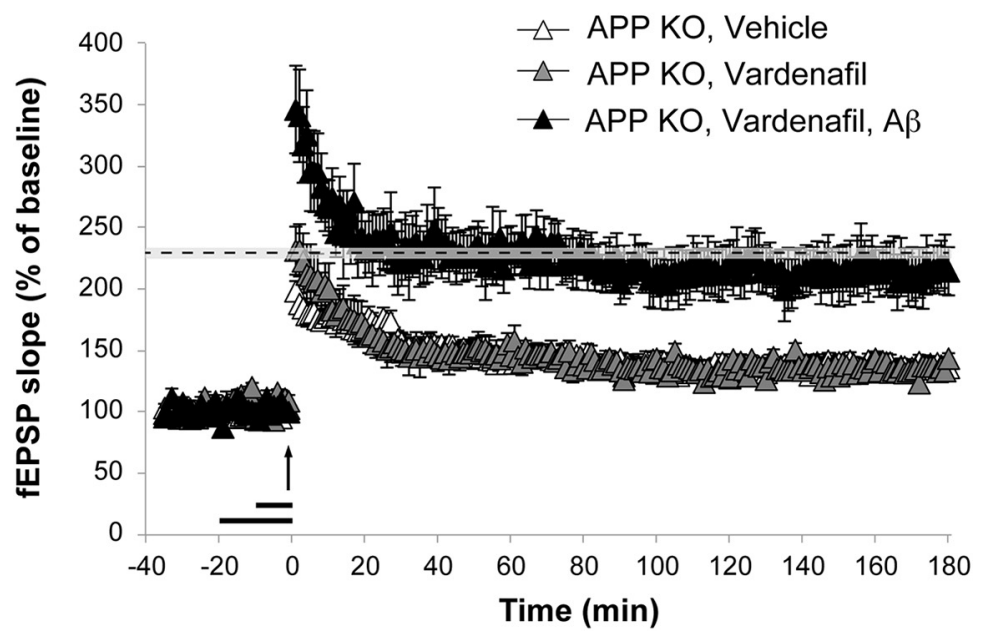

Figure 4. cGMP-induced conversion of e-LTP into I-LTP requires A $\beta$. A, Perfusion of hippocampal slices with $50 \mathrm{~nm}$ sildenafil or $10 \mathrm{~nm}$ vardenafil for 10 min before a weak tetanus is able to convert e-LTP in I-LTP (vehicle: $n=7 ; 134.96 \pm 4.19 \%$ of baseline slope 180 min after tetanus; sildenafil: $n=5 ; 196.72 \pm 11.11 \%$ of baseline slope; vardenafil: $n=7 ; 214.86 \pm 11.75 \%$ of baseline slope). The PDE5-I-induced I-LTP is comparable to I-LTP evoked by a strong tetanus $(n=7 ; 227.41 \pm 6.79 \%$ of baseline slope 180 min after tetanus). $\boldsymbol{B}$, A concomitant perfusion with a monoclonal anti-A $\beta$ antibody (M3.2 mAb; $2 \mu \mathrm{g} / \mathrm{ml}$ ) for 20 min before a weak tetanus suppresses the vardenafil-enhancing effect on LTP ( $n=7 ; 123.25 \pm 4.60 \%$ of baseline slope 180 min after tetanus). levels, we performed additional experiments to study the effect of vardenafil at $100 \mu \mathrm{M}$ on LTP induced by a strong tetanus. We found that a treatment with vardenafil $100 \mu \mathrm{M}$ was capable of inducing a significant increase in LTP compared with vehicle-treated slices $(360.90 \pm 33.95$ vs $227.41 \pm 6.79 \%$ of baseline; $F_{(1,12)}=$ 28.692, $p<0.0001$ comparing vehicle + strong tetanus vs $100 \mu \mathrm{M}$ vardenafil + strong tetanus; data not shown).

Given that the experiments shown in Figure 1 demonstrated cGMP-induced $\mathrm{A} \beta$ secretion, and in previous studies we have proved that low picomolar concentrations of $A \beta$ are capable of enhancing LTP (Puzzo et al., 2008, 2012), we wanted to verify whether the cGMP-induced conversion of e-LTP in l-LTP depends upon $\mathrm{A} \beta$. To this end, we examined whether vardenafil was still capable of inducing 1-LTP after depletion of endogenous murine $A \beta$. Hippocampal slices were treated with a monoclonal antirodent $\mathrm{A} \beta$ antibody (M3.2 mAb; $2 \mu \mathrm{g} / \mathrm{ml}$ ) for $20 \mathrm{~min}$ before the weak tetanus (Ricciarelli et al., 2014). M3.2 antibody is a monoclonal antibody with a selective affinity for murine $\mathrm{A} \beta$, which has been fully characterized in previous studies for its capability to block $\mathrm{A} \beta$ in both physiological and pathological conditions (Morales-Corraliza et al., 2009, 2013; Wesson et al., 2013). Moreover, in those studies and in previous experiments performed in our laboratory (Puzzo et al., 2011), control IgG antibodies (i.e., IgG2a isotype-matched control antibody that does not bind to any rodent proteins) have been used to demonstrate the specificity of M3.2 for rodent $\mathrm{A} \beta$.

Here, when we blocked endogenous $\mathrm{A} \beta$ with M3.2, vardenafil was no longer capable of eliciting l-LTP $\left(F_{(1,12)}=48.135\right.$, $p<0.0001$ compared with vardenafil + weak tetanus; $F_{(1,12)}=183.422, p<$ 0.0001 compared with vehicle + strong tetanus; Figure 4B). Importantly, M3.2 $\mathrm{mAb}$ alone did not modify early-LTP induced by a weak tetanus $\left(F_{(1,12)}=2.712\right.$,

\section{$\leftarrow$}

Vardenafil-induced I-LTP is rescued by perfusion with human $\mathrm{A} \beta_{42}(200 \mathrm{pm})$ in slices concurrently treated with M3.2 $(n=8$; $213.51 \pm 34.17 \%$ of baseline slope 180 min after tetanus). C, 200 рм A $\beta_{42}$ rescues the vardenafil-induced I-LTP in slices obtained from APP K0 mice $(n=7 / 7 ; 143.27 \pm 10.69 \%$ of baseline slope $180 \mathrm{~min}$ after tetanus vs $214.47 \pm 19.68 \%$ of baseline slope $180 \mathrm{~min}$ after tetanus). The horizontal bar indicates the period during which drugs are added to the bath solution. The arrow indicates tetanus delivery. The shaded areas in $\boldsymbol{B}$ and $\boldsymbol{C}$ correspond to the average potentiation (dotted line) and the SE range in slices treated with vehicle + strong tetanus as in $\boldsymbol{A}$. Data are mean \pm SEM. 
$p=0.125$, compared with vehicle + weak tetanus; Fig. $4 B)$, excluding that M3.2 blocked potentiation per se, as occurring when blocking endogenous $A \beta$ before a strong stimulation used to induce l-LTP (Puzzo et al., 2011). Thus, an antirodent $A \beta$ antibody, which sequesters the endogenously produced peptide, prevented the well known potentiating effects of vardenafil on LTP, suggesting that endogenous $A \beta$ is needed for this effect to occur.

M3.2 mAb also recognizes $\beta$-CTF, soluble APP $\alpha$, and fulllength APP. Thus, it might exert an effect independent of $A \beta$ depletion by binding to other targets. To further support the involvement of $\mathrm{A} \beta$ in the cGMP-induced LTP, we performed rescue experiments with exogenous human $\mathrm{A} \beta_{42}$, which is not recognized by the M3.2 mAb. In fact, in the presence of M3.2 (sequestering vardenafil-induced endogenous $A \beta$ production), exogenously added human $A \beta$ was able to restore l-LTP to the same level of that observed in the absence of the antibody $\left(F_{(1,13)}=\right.$ $0.410, p=0.533$ compared with vardenafil + weak tetanus; $F_{(1,13)}=$ $0.740, p=0.405$ compared with vehicle + strong tetanus; Figure $4 B)$. This rescue experiment demonstrated that the abolishment of the cGMP-induced LTP was specifically due to the lack of $A \beta$.

To further confirm these findings with an independent strategy, we provided genetic evidence for the involvement of $A \beta$ in cGMP-induced synaptic plasticity increase. We performed additional experiments using APP KO mice that do not produce A $\beta$. When hippocampal slices from these animals were perfused with vardenafil, the drug failed to enhance LTP $\left(F_{(1,12)}=28.846, p<\right.$ 0.0001 compared with WT slices treated with vardenafil + weak tetanus; $F_{(1,12)}=77.172, p<0.0001$ compared with WT slices treated with vehicle + strong tetanus; Figure $4 C$ ). Moreover, addition of $200 \mathrm{pm}$ human synthetic $\mathrm{A} \beta_{42}$ was capable of eliciting 1-LTP in APP KO slices treated with vardenafil $\left(F_{(1,12)}=0.126\right.$, $p=0.729$ compared with WT treated with vardenafil + weak tetanus; $F_{(1,12)}=0.514, p=0.487$ compared with WT treated with vehicle + strong tetanus; Figure $4 C$ ). Together these findings demonstrate that $A \beta$ is required for the cGMP-induced conversion of e-LTP into l-LTP.

\section{$A \beta$ is required for cGMP-induced memory}

The electrophysiological results prompted us to evaluate whether $A \beta$ is required for cGMP-induced memory. To this end we used WT and APP KO mice. We studied recognition memory by the ORT, a task based on the natural tendency of rodents to explore unfamiliar objects, which relies on the integrity of hippocampus and parahippocampal regions (Broadbent et al., 2010). After $3 \mathrm{~d}$ of habituation, mice underwent training (T1) in which they were presented with two identical objects for 3 min. Right after T1 animals were treated with vehicle or vardenafil $(1 \mathrm{mg} / \mathrm{kg}$, i.p.; Bollen et al., 2014). After $24 \mathrm{~h}$ (T2), animals were put back in the arena containing the "familiar" object (the same as in T1) and the "novel" object. Mice were allowed to explore the objects for $3 \mathrm{~min}$ and exploration time was recorded and scored. WT mice treated with vehicle showed the natural forgetting, due to the short time exposure in $\mathrm{T} 1$ and the long $24 \mathrm{~h}$ interval between $\mathrm{T} 1$ and $\mathrm{T} 2$. Indeed, there was no difference between the percentage time spent exploring the novel object and that spent exploring the familiar object in WT vehicle-treated animals $\left(t_{(22)}=0.698 ; p=\right.$ 0.492; Fig. 5A). As previously demonstrated (Bollen et al., 2014), treatment with vardenafil produced memory because animals spent more time exploring the novel object in $\mathrm{T} 2\left(t_{(22)}=5.538\right.$; $p<0.0001$; Fig. $5 A$ ). As for the LTP experiments, this effect was not present in APP KO littermates. $\left(t_{(24)}=0.845 ; p=0.407\right.$; Fig. $5 A)$. Analyses of $\mathrm{D}$ confirmed a difference among groups $\left(F_{(3,45)}=\right.$ $3.446, p=0.024)$ and indicated that only WT mice treated with vardenafil recognized the familiar object (Bonferroni's $p=0.02$ ) because their $\mathrm{D}$ significantly differed from $0\left(t_{(12)}=0.597 ; p=\right.$ $0.561 ;$ Fig. $5 B)$. No differences were detected in latency to approach the novel object for the first time $\left(F_{(3,45)}=0.359, p=0.783\right.$; Fig. $\left.5 C\right)$ and in total exploration time $\left(F_{(3,45)}=0.762, p=0.521\right.$; Fig. $\left.5 D\right)$, suggesting that the treatment did not modify anxiety and motor activity. Together, these experiments demonstrate that cGMPinduced memory cannot be evoked in APP KO mice.

\section{Discussion}

From the early 1990s, $A \beta$ has been found to be a physiological product of cellular metabolism, but studies on the mechanisms underlying its production and degradation have mainly aimed at better understanding the pathophysiology of $\mathrm{AD}$. However, there is a growing body of evidence suggesting that $\mathrm{A} \beta$ regulates synaptic function and memory in the healthy brain (Puzzo and Arancio, 2013; Fedele et al., 2015; Puzzo et al., 2015). To understand the mechanism by which this occurs, we have investigated the role of cGMP in the phenomenon because the cyclic nucleotide is involved in synaptic plasticity and memory (Bernabeu et al., 1996; Son et al., 1998; Lu et al., 1999). Our data show that increase in cGMP levels, obtained by using the PDE5-Is sildenafil or vardenafil, induces a parallel increase of $A \beta$ secretion in two different models, N2a cells and rat hippocampal slices. This effect was reduced when cells were pretreated with ODQ, a selective inhibitor of sGC, confirming that $\mathrm{A} \beta$ production is regulated by cGMP.

Considering that our previous reports indicated that cAMP influences APP synthesis (Tang et al., 2012; Canepa et al., 2013; Ricciarelli et al., 2014; Das et al., 2016), we first investigated whether cGMP modifies APP expression, but we did not find any change in APP levels both in N2a cells and hippocampal slices treated with vardenafil. A possible explanation for this finding is that we measured total APP full-length which is present in several cell compartments (endoplasmic reticulum, trans-Golgi network, etc.), and therefore any change in local APP expression might have gone undetected, especially in light of increasing evidence indicating that BACE1 cleavage of APP, the rate-limiting step in $A \beta$ production (O'Brien and Wong, 2011), occurs predominantly in the endolysosomal compartment (for review, see: Thinakaran and Koo, 2008; Wilkins and Swerdlow, 2016). Therefore, we hypothesize that the enhancement of $A \beta$ production by vardenafil involves processing of a fraction of the precursor protein that does not significantly impact the levels of total APP. Consistent with this scenario, we found that the cGMP increase does not induce a generic activation of BACE-1, but rather stimulates APP and BACE-1 to converge in the endolysosomal compartment where amyloidogenic processing is favored. Recent reports on the distinct distribution of amyloidogenic enzymes in late endosome/lysosomes corroborate our observation (Das et al., 2016; Sannerud et al., 2016). Moreover, these results are consistent with previous studies demonstrating that a treatment with the PDE5-I sildenafil induces a slight increase of $\mathrm{A} \beta$ without affecting APP full-length expression in healthy mice (Puzzo et al., 2014).

It could be argued that the cGMP-induced increase of $\mathrm{A} \beta$ levels might be harmful, because high concentrations of $\mathrm{A} \beta$ are commonly associated with the characteristic impairment of cognition in $\mathrm{AD}$. Yet, the $\mathrm{A} \beta$ increase that we detected in our studies is in the picomolar range, a concentration known to produce physiological positive effects (Puzzo et al., 2008). Our findings might also appear controversial in light of most of the scientific literature recommending the use of PDE-Is to reduce $\mathrm{A} \beta$ levels. 
A

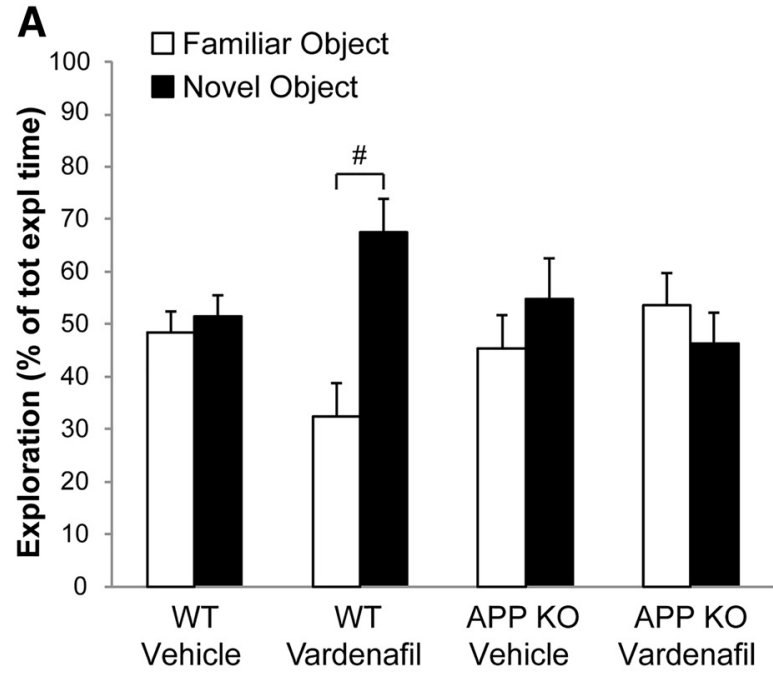

B

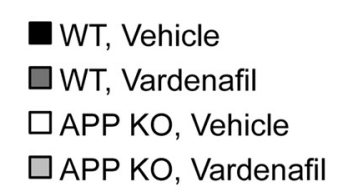

C

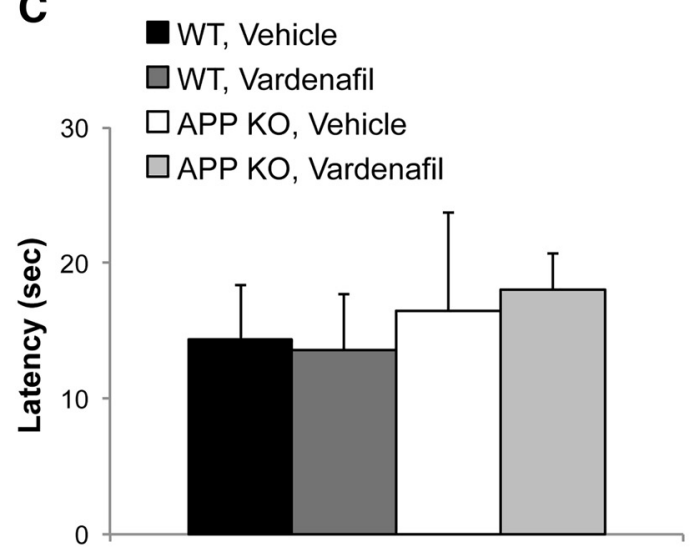

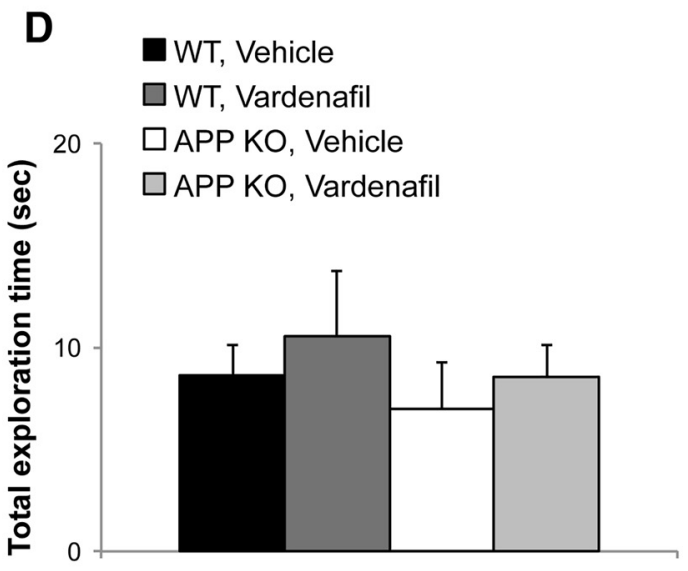

Figure 5. CGMP-induced recognition memory is not present in APP KO mice. $A$, Exploration times of familiar and novel object during $\mathrm{T} 2$ (after a $24 \mathrm{~h}$ retention interval) show that WT mice treated with vardenafil spend longer time exploring the novel object ( $n=12 ; 65.45 \pm 6.34$ vs $32.43 \pm 6.34 \%$ of total exploration time). Conversely, vardenafil is not able to evoke memory in APP K0 mice ( $n=13 ; 46.32 \pm 5.93$ vs $53.67 \pm 5.93 \%$ of total exploration time). WT and APP K0 mice treated with vehicle spend the same amount of time exploring the familiar and the novel object (WT: $n=$ $12 ; 51.47 \pm 3.9$ vs $48.52 \pm 3.9 \%$ of total exploration time; APP K0: $n=12 ; 54.72 \pm 7.87$ vs $45.27 \pm 7.87 \%$ of total exploration time), confirming the physiological forgetting due to the shorter exposition in T1. $\boldsymbol{B}$, Analyses of the D confirm that vardenafil-induced enhancement of recognition memory is not evoked in APP K0 mice. $\boldsymbol{C}$, Latency to first approach to the novel object and (D) total exploration time are comparable in the four groups of mice. ${ }^{*} p<0.05 ; \# p<0.0001$; §difference from 0 . Data are mean \pm SEM.

However, these studies have been performed in models of $\mathrm{A} \beta$ hyper-production, i.e., AD transgenic animals (Puzzo et al., 2009; Zhang et al., 2013; Zhu et al., 2015). Thus, it could be feasible to hypothesize that cGMP exerts opposite effects in physiological or pathological conditions characterized by low or high levels of $A \beta$, respectively. In this context, it is also interesting to note that either $\mathrm{A} \beta$ or cGMP behave in a hormetic fashion (Andoh et al., 2003; Puzzo et al., 2012), stimulating or inhibiting cellular functions based on the applied dose. Other studies have found that NO donors, such as sodium nitroprusside, bidirectionally modulates APP processing depending upon the concentration used (Cai et al., 2016). On the other side, it has been shown that high concentrations of $A \beta$ determine a decrease of cGMP in different cell and animal models (Bonkale et al., 1995; Chalimoniuk and Strosznajder, 1998; Baltrons et al., 2002, 2004). Intriguingly, in patients diagnosed with mild AD, cognitive impairment and CSF $\mathrm{A} \beta_{42}$ levels were significantly associated with a decrease in cGMP content (Ugarte et al., 2015). An overview of these findings might suggest the existence of a physiological feedback cGMP-A $\beta$ axis, i.e., the increase of $\mathrm{cGMP}$ stimulates $\mathrm{A} \beta$ production that, in turn, inhibits cGMP production via a negative feedback mechanism.
This hypothesis might justify the reduction of cGMP induced by an abnormal increase of $A \beta$ levels, and the reduction of $A \beta$ levels after a chronic administration of cGMP-enhancing drugs such as PDE-Is.

Hippocampal LTP can be induced through several tetanization protocols including the $\theta$-burst stimulation. A weak tetanus leads to e-LTP, which lasts $\sim 1 \mathrm{~h}$ and is protein synthesis independent, whereas a strong tetanus leads to l-LTP, which lasts longer and is protein or RNA synthesis dependent (Huang et al., 1996). Here, we have found that elevation of cGMP levels transforms e-LTP into l-LTP. This finding is consistent with the observation that the NO/cGMP signaling, first thought to be involved only in e-LTP, plays a role also in l-LTP (Bernabeu et al., 1996; Son et al., 1998; Lu et al., 1999; Bollen et al., 2014). Moreover, this observation is consistent with the observation that stimulation of the NO/cGMP signaling participates to memory formation and consolidation (Prickaerts et al., 2002; Rutten et al., 2008, Bollen et al., 2014).

Considering that we and others have previously demonstrated that $\mathrm{A} \beta$ is also needed for LTP and memory formation (Puzzo et al., 2011), and it has a positive modulatory effect on these phe- 
nomena when administered at physiological concentrations (Puzzo et al., 2008; Morley et al., 2010; Lawrence et al., 2014), we wanted to investigate whether the cGMP-induced LTP and memory was related to $\mathrm{A} \beta$ production. Here we show that vardenafilinduced enhancement of synaptic plasticity and memory requires $\mathrm{A} \beta$ to occur. Indeed, removing $\mathrm{A} \beta$ by immunological (anti-A $\beta$ antibodies) or genetic (APP KO) manipulation prevents the cGMPdependent enhancement of LTP and memory. This is consistent with previous data showing that when blocking $\mathrm{A} \beta$ function with an APP siRNA or a monoclonal anti-A $\beta$ antibody, LTP induced by a strong tetanus was impaired, but it could be rescued by administration of $200 \mathrm{pm} \mathrm{A} \beta$ that should restore the physiological content of the peptide in the brain (Puzzo et al., 2011). When a higher concentration of $\mathrm{A} \beta(300 \mathrm{pM})$ was added together with the anti-A $\beta$ antibody, LTP was further enhanced compared with vehicle-treated slices. However, in the same work (Puzzo et al., 2011) we demonstrated that young APP KO present normal LTP, consistent with other studies showing that APP KO mice present abnormalities in neuronal morphology and LTP at 12-15 months of age, whereas younger mice are normal (Tyan et al., 2012). This might be due to compensation mechanisms that are known to occur in genetically modified animals. Here, we used young APP KO mice that do not produce $A \beta$ but still have a normal LTP. In this way, the fact that vardenafil was not able to induce l-LTP in APP KO mice could not be attributable to an impairment of 1-LTP per se.

In rescue experiments, exogenous human $\mathrm{A} \beta$ was able to restore 1-LTP in slices treated with an anti-rodent $A \beta$ antibody, confirming that $\mathrm{A} \beta$ was needed for the vardenafil-induced l-LTP. It is interesting to note that, as in previous works (Puzzo et al., $2008,2011,2012$ ), we have used a solution of human $\mathrm{A} \beta$ containing both monomers and oligomers to rescue the l-LTP impairment due to an inhibition of endogenous murine $\mathrm{A} \beta$, that is thought to be less prone to oligomerize. Thus, one might interpret our results through an effect of $\mathrm{A} \beta$ monomers. However, it should be taken into account that oligomers cannot be excluded in light of some recent studies showing that also murine $\mathrm{A} \beta$ might form aggregates and deposits. For example, it has been shown that SAMP8 mice present an increase of murine $\mathrm{A} \beta_{42}$ oligomers (Li et al., 2009) and that murine $A \beta$ overproduction might produce deposits similar to human AD plaques (Xu et al., 2015).

As for the behavioral experiments, APP KO mice lack not only $\mathrm{A} \beta$, but also all the other APP proteolytic fragments that could be responsible, at least in theory, for the effects induced by vardenafil on memory. However, these results completed a series of experiments demonstrating that: 1) by enhancing cGMP, PDE5 inhibitors increase $\mathrm{A} \beta$ levels in an ODQ-sensitive manner; and 2) the effect of vardenafil on hippocampal LTP, the generally accepted electrophysiological correlate of memory formation and consolidation, is abrogated by antirodent $\mathrm{A} \beta$ antibody, but it can be rescued by addition of exogenous human $A \beta$. Therefore, our behavioral analysis supports the hypothesis that cGMP stimulates $\mathrm{A} \beta$ production, which is instrumental for $\mathrm{cGMP}$ to boost hippocampal LTP and memory.

Similar to the current findings showing that $A \beta$ is required for cGMP-induced hippocampal l-LTP and memory, we previously reported that increasing endogenous cAMP through PDE4 inhibition also requires $\mathrm{A} \beta$ to enhance hippocampal LTP (Ricciarelli et al., 2014). The fact that cGMP and cAMP are known to cooperate in synaptic plasticity and memory processes and that both act through $\mathrm{A} \beta$ production lays the basis for a novel interpretation of synaptic mechanisms that deserve further investigation in the future.
In conclusion, we have found a tight relationship between cGMP and $\mathrm{A} \beta$, demonstrating that $\mathrm{cGMP}$ acts upstream of $\mathrm{A} \beta$ by regulating its secretion, a sine qua non for LTP and memory to work in physiological conditions. Our findings might be useful to better understand the mechanism of action of drugs increasing cGMP levels, such as PDE5-Is, that might enhance cognition via a positive modulation of $\mathrm{A} \beta$ in the healthy brain. Most importantly, these experiments stress the relevance of fully understanding the physiological role(s) of $A \beta$ to design effective and safe approaches to $\mathrm{AD}$ therapy, as $\mathrm{A} \beta$ lowering treatments might lead to memory worsening instead of amelioration.

\section{References}

Andoh T, Chiueh CC, Chock PB (2003) Cyclic GMP-dependent protein kinase regulates the expression of thioredoxin and thioredoxin peroxidase-1 during hormesis in response to oxidative stress-induced apoptosis. J Biol Chem 278:885-890. CrossRef Medline

Arancio O, Kandel ER, Hawkins RD (1995 Jul 6) Activity-dependent longterm enhancement of transmitter release by presynaptic $3^{\prime}, 5^{\prime}$-cyclic GMP in cultured hippocampal neurons. Nature 376:74-80. CrossRef Medline

Baltrons MA, Pedraza CE, Heneka MT, García A (2002) Beta-amyloid peptides decrease soluble guanylyl cyclase expression in astroglial cells. Neurobiol Dis 10:139-149. CrossRef Medline

Baltrons MA, Pifarré P, Ferrer I, Carot JM, García A (2004) Reduced expression of NO-sensitive guanylyl cyclase in reactive astrocytes of Alzheimer disease, Creutzfeldt-Jakob disease, and multiple sclerosis brains. Neurobiol Dis 17:462-472. CrossRef Medline

Bernabeu R, Schmitz P, Faillace MP, Izquierdo I, Medina JH (1996) Hippocampal cGMP and cAMP are differentially involved in memory processing of inhibitory avoidance learning. Neuroreport 7:585-588. CrossRef Medline

Bollen E, Puzzo D, Rutten K, Privitera L, De Vry J, Vanmierlo T, Kenis G, Palmeri A, D'Hooge R, Balschun D, Steinbusch HM, Blokland A, Prickaerts J (2014) Improved long-term memory via enhancing cGMP-PKG signaling requires cAMP-PKA signaling. Neuropsychopharmacology 39: 2497-2505. CrossRef Medline

Bonkale WL, Winblad B, Ravid R, Cowburn RF (1995) Reduced nitric oxide responsive soluble guanylyl cyclase activity in the superior temporal cortex of patients with Alzheimer's disease. Neurosci Lett 187:5-8. CrossRef Medline

Broadbent NJ, Gaskin S, Squire LR, Clark RE (2010) Object recognition memory and the rodent hippocampus. Learn Mem 17:5-11. CrossRef Medline

Cai ZX, Guo HS, Wang C, Wei M, Cheng C, Yang ZF, Chen YW, Le WD, Li S (2016) Double-edged roles of nitric oxide signaling on APP processing and amyloid- $\beta$ production in vitro: preliminary evidence from sodium nitroprusside. Neurotox Res 29:21-34. CrossRef Medline

Canepa E, Domenicotti C, Marengo B, Passalacqua M, Marinari UM, Pronzato MA, Fedele E, Ricciarelli R (2013) Cyclic adenosine monophosphate as an endogenous modulator of the amyloid- $\beta$ precursor protein metabolism. IUBMB Life 65:127-133. CrossRef Medline

Chalimoniuk M, Strosznajder JB (1998) Aging modulates nitric oxide synthesis and cGMP levels in hippocampus and cerebellum: effects of amyloid beta peptide. Mol Chem Neuropathol 35:77-95. CrossRef Medline

Cheng YF, Wang C, Lin HB, Li YF, Huang Y, Xu JP, Zhang HT (2010) Inhibition of phosphodiesterase- 4 reverses memory deficits produced by $\mathrm{A} \beta 25-35$ or A $\beta 1-40$ peptide in rats. Psychopharmacology (Berl) 212: 181-191. CrossRef Medline

Cirrito JR, Yamada KA, Finn MB, Sloviter RS, Bales KR, May PC, Schoepp DD, Paul SM, Mennerick S, Holtzman DM (2005) Synaptic activity regulates interstitial fluid amyloid-beta levels in vivo. Neuron 48:913-922. CrossRef Medline

Das U, Wang L, Ganguly A, Saikia JM, Wagner SL, Koo EH, Roy S (2016) Visualizing APP and BACE-1 approximation in neurons yields insight into the amyloidogenic pathway. Nat Neurosci 19:55-64. CrossRef Medline

Fedele E, Rivera D, Marengo B, Pronzato MA, Ricciarelli R (2015) Amyloidbeta: walking on the dark side of the moon. Mech Ageing Dev 152:1-4. CrossRef Medline

Gong B, Vitolo OV, Trinchese F, Liu S, Shelanski M, Arancio O (2004) Persistent improvement in synaptic and cognitive functions in an Alzhei- 
mer mouse model after rolipram treatment. J Clin Invest 114:1624-1634. CrossRef Medline

Huang YY, Nguyen PV, Abel T, Kandel ER (1996) Long-lasting forms of synaptic potentiation in the mammalian hippocampus. Learn Mem 3:7485. CrossRef Medline

Kamenetz F, Tomita T, Hsieh H, Seabrook G, Borchelt D, Iwatsubo T, Sisodia S, Malinow R (2003) APP processing and synaptic function. Neuron 37:925-937. CrossRef Medline

Kerppola TK (2006) Design and implementation of bimolecular fluorescence complementation (BiFC) assays for the visualization of protein interactions in living cells. Nat Protoc 1:1278-1286. CrossRef Medline

Lawrence JL, Tong M, Alfulaij N, Sherrin T, Contarino M, White MM, Bellinger FP, Todorovic C, Nichols RA (2014) Regulation of presynaptic $\mathrm{Ca} 2+$, synaptic plasticity and contextual fear conditioning by a $\mathrm{N}$-terminal $\beta$-amyloid fragment. J Neurosci 34:14210-14218. CrossRef Medline

Lee HR, Shin HK, Park SY, Kim HY, Lee WS, Rhim BY, Hong KW, Kim CD (2014) Cilostazol suppresses $\beta$-amyloid production by activating a disintegrin and metalloproteinase 10 via the upregulation of SIRT1-coupled retinoic acid receptor- $\beta$. J Neurosci Res 92:1581-1590. CrossRef Medline

Li Q, Zhao HF, Zhang ZF, Liu ZG, Pei XR, Wang JB, Li Y (2009) Long-term green tea catechin administration prevents spatial learning and memory impairment in senescence-accelerated mouse prone- 8 mice by decreasing $\mathrm{A} \beta_{1-42}$ oligomers and upregulating synaptic plasticity-related proteins in the hippocampus. Neuroscience 163:741-749. CrossRef Medline

Lu YF, Kandel ER, Hawkins RD (1999) Nitric oxide signaling contributes to late-phase LTP and CREB phosphorylation in the hippocampus. J Neurosci 19:10250-10261. Medline

Monfort P, Muñoz MD, Kosenko E, Felipo V (2002) Long-term potentiation in hippocampus involves sequential activation of soluble guanylate cyclase, cGMP-dependent protein kinase, and cGMP-degrading phosphodiesterase. J Neurosci 22:10116-10122. Medline

Morales-Corraliza J, Mazzella MJ, Berger JD, Diaz NS, Choi JH, Levy E, Matsuoka Y, Planel E, Mathews PM (2009) In vivo turnover of tau and APP metabolites in the brains of wild-type and $\mathrm{Tg} 2576$ mice: greater stability of sAPP in the beta-amyloid depositing mice. PLoS One 4:e7134. CrossRef Medline

Morales-Corraliza J, Schmidt SD, Mazzella MJ, Berger JD, Wilson DA, Wesson DW, Jucker M, Levy E, Nixon RA, Mathews PM (2013) Immunization targeting a minor plaque constituent clears $\beta$-amyloid and rescues behavioral deficits in an Alzheimer's disease mouse model. Neurobiol Aging 34:137-145. CrossRef Medline

Morley JE, Farr SA, Banks WA, Johnson SN, Yamada KA, Xu L (2010) A physiological role for amyloid-beta protein: enhancement of learning and memory. J Alzheimers Dis 19:441-449. CrossRef Medline

O'Brien RJ, Wong PC (2011) Amyloid precursor protein processing and Alzheimer's disease. Annu Rev Neurosci 34:185-204. CrossRef Medline

Orejana L, Barros-Miñones L, Jordán J, Puerta E, Aguirre N (2012) Sildenafil ameliorates cognitive deficits and tau pathology in a senescenceaccelerated mouse model. Neurobiol Aging 33:625.e11-20. CrossRef Medline

Palmeri A, Privitera L, Giunta S, Loreto C, Puzzo D (2013) Inhibition of phosphodiesterase- 5 rescues age-related impairment of synaptic plasticity and memory. Behav Brain Res 240:11-20. CrossRef Medline

Prickaerts J, van Staveren WC, Sik A, Markerink-van Ittersum M, Niewöhner U, van der Staay FJ, Blokland A, de Vente J (2002) Effects of two selective phosphodiesterase type 5 inhibitors, sildenafil and vardenafil, on object recognition memory and hippocampal cyclic GMP levels in the rat. Neuroscience 113:351-361. CrossRef Medline

Puzzo D, Arancio O (2013) Amyloid- $\beta$ peptide: Dr. Jekyll or Mr. Hyde? J Alzheimers Dis 33:S111-120. CrossRef Medline

Puzzo D, Vitolo O, Trinchese F, Jacob JP, Palmeri A, Arancio O (2005) Amyloid- $\beta$ peptide inhibits activation of the nitric oxide/cGMP/cAMPresponsive element-binding protein pathway during hippocampal synaptic plasticity. J Neurosci 25:6887-6897. CrossRef Medline

Puzzo D, Privitera L, Leznik E, Fà M, Staniszewski A, Palmeri A, Arancio O (2008) Picomolar amyloid- $\beta$ positively modulates synaptic plasticity and memory in hippocampus. J Neurosci 28:14537-14545. CrossRef Medline

Puzzo D, Staniszewski A, Deng SX, Privitera L, Leznik E, Liu S, Zhang H, Feng Y, Palmeri A, Landry DW, Arancio O (2009) Phosphodiesterase 5 inhibition improves synaptic function, memory, and amyloid- $\beta$ load in an Alzheimer's disease mouse model. J Neurosci 29:8075-8086. CrossRef Medline
Puzzo D, Privitera L, Fa’ M, Staniszewski A, Hashimoto G, Aziz F, Sakurai M, Ribe EM, Troy CM, Mercken M, Jung SS, Palmeri A, Arancio O (2011) Endogenous amyloid- $\beta$ is necessary for hippocampal synaptic plasticity and memory. Ann Neurol 69:819-830. CrossRef Medline

Puzzo D, Privitera L, Palmeri A (2012) Hormetic effect of amyloid- $\beta$ peptide in synaptic plasticity and memory. Neurobiol Aging 33:1484.e15-24. CrossRef Medline

Puzzo D, Loreto C, Giunta S, Musumeci G, Frasca G, Podda MV, Arancio O, Palmeri A (2014) Effect of phosphodiesterase-5 inhibition on apoptosis and beta amyloid load in aged mice. Neurobiol Aging 35:520-531. CrossRef Medline

Puzzo D, Gulisano W, Arancio O, Palmeri A (2015) The keystone of Alzheimer pathogenesis might be sought in $\mathrm{A} \beta$ physiology. Neuroscience 307: 26-36. CrossRef Medline

Ricciarelli R, Fedele E (2017) The amyloid cascade hypothesis in Alzheimer's disease: it's time to change our mind. Curr Neuropharmacol. Advance online publication. Retrieved January 16, 2017. doi: 10.2174/ 1570159X15666170116143743. Medline

Ricciarelli R, Puzzo D, Bruno O, Canepa E, Gardella E, Rivera D, Privitera L, Domenicotti C, Marengo B, Marinari UM, Palmeri A, Pronzato MA, Arancio O, Fedele E (2014) A novel mechanism for cyclic adenosine monophosphate-mediated memory formation: role of amyloid beta. Ann Neurol 75:602-607. CrossRef Medline

Rutten K, Vente JD, Sik A, Ittersum MM, Prickaerts J, Blokland A (2005) The selective PDE5 inhibitor, sildenafil, improves object memory in Swiss mice and increases cGMP levels in hippocampal slices. Behav Brain Res 164:11-16. CrossRef Medline

Rutten K, Basile JL, Prickaerts J, Blokland A, Vivian JA (2008) Selective PDE inhibitors rolipram and sildenafil improve object retrieval performance in adult cynomolgus macaques. Psychopharmacology (Berl) 196:643648. CrossRef Medline

Sakurai H, Hanyu H, Sato T, Kume K, Hirao K, Kanetaka H, Iwamoto T (2013) Effects of cilostazol on cognition and regional cerebral blood flow in patients with Alzheimer's disease and cerebrovascular disease: a pilot study. Geriatr Gerontol Int 13:90-97. CrossRef Medline

Sannerud R, Esselens C, Ejsmont P, Mattera R, Rochin L, Tharkeshwar AK, De Baets G, De Wever V, Habets R, Baert V, Vermeire W, Michiels C, Groot AJ, Wouters R, Dillen K, Vints K, Baatsen P, Munck S, Derua R, Waelkens E, et al. (2016) Restricted location of PSEN2/ $\gamma$-secretase determines substrate specificity and generates an intracellular $\mathrm{A} \beta$ pool. Cell 166:193-208. CrossRef Medline

Shim YS, Pae CU, Kim SW, Kim HW, Kim JC, Koh JS (2011) Effects of repeated dosing with Udenafil (Zydena) on cognition, somatization and erection in patients with erectile dysfunction: a pilot study. Int J Impot Res 23:109-114. CrossRef Medline

Son H, Lu YF, Zhuo M, Arancio O, Kandel ER, Hawkins RD (1998) The specific role of cGMP in hippocampal LTP. Learn Mem 5:231-245. Medline

Tang Y, Scott DA, Das U, Edland SD, Radomski K, Koo EH, Roy S (2012) Early and selective impairments in axonal transport kinetics of synaptic cargoes induced by soluble amyloid $\beta$-protein oligomers. Traffic 13:681693. CrossRef Medline

Teich AF, Nicholls RE, Puzzo D, Fiorito J, Purgatorio R, Fa' M, Arancio O (2015) Synaptic therapy in Alzheimer's disease: a CREB-centric approach. Neurotherapeutics 12:29-41. CrossRef Medline

Thinakaran G, Koo EH (2008) Amyloid precursor protein trafficking, processing, and function. J Biol Chem 283:29615-29619. CrossRef Medline

Tyan SH, Shih AY, Walsh JJ, Maruyama H, Sarsoza F, Ku L, Eggert S, Hof PR, Koo EH, Dickstein DL (2012) Amyloid precursor protein (APP) regulates synaptic structure and function. Mol Cell Neurosci 51:43-52. CrossRef Medline

Ugarte A, Gil-Bea F, García-Barroso C, Cedazo-Minguez Á, Ramírez MJ, Franco R, García-Osta A, Oyarzabal J, Cuadrado-Tejedor M (2015) Decreased levels of guanosine $3^{\prime}, 5^{\prime}$-monophosphate (cGMP) in cerebrospinal fluid (CSF) are associated with cognitive decline and amyloid pathology in Alzheimer's disease. Neuropathol Appl Neurobiol 41:471482. CrossRef Medline

Vitolo OV, Sant'Angelo A, Costanzo V, Battaglia F, Arancio O, Shelanski M (2002) Amyloid beta-peptide inhibition of the PKA/CREB pathway and long-term potentiation: reversibility by drugs that enhance cAMP signaling. Proc Natl Acad Sci U S A 99:13217-13221. CrossRef Medline 
Wesson DW, Morales-Corraliza J, Mazzella MJ, Wilson DA, Mathews PM (2013) Chronic anti-murine $A \beta$ immunization preserves odor guided behaviors in an Alzheimer's $\beta$-amyloidosis model. Behav Brain Res 237: 96-102. CrossRef Medline

Wilkins HM, Swerdlow RH (2016) Amyloid precursor protein processing and bioenergetics. Brain Res Bull S0361-9230(16)30204-0. CrossRef Medline

Xu G, Ran Y, Fromholt SE, Fu C, Yachnis AT, Golde TE, Borchelt DR (2015) Murine $\mathrm{A} \beta$ over-production produces diffuse and compact Alzheimer-type amyloid deposits. Acta Neuropathol Commun 3:72. CrossRef Medline

Yamamoto M, Götz ME, Ozawa H, Luckhaus C, Saito T, Rösler M, Riederer P (2000) Hippocampal level of neural specific adenylyl cyclase type I is decreased in Alzheimer's disease. Biochim Biophys Acta 1535:60-68. CrossRef Medline

Zhang J, Guo J, Zhao X, Chen Z, Wang G, Liu A, Wang Q, Zhou W, Xu Y, Wang C (2013) Phosphodiesterase-5 inhibitor sildenafil prevents neuroinflammation, lowers beta-amyloid levels and improves cognitive performance in APP/PS1 transgenic mice. Behav Brain Res 250:230-237. CrossRef Medline

Zhu L, Yang JY, Xue X, Dong YX, Liu Y, Miao FR, Wang YF, Xue H, Wu CF (2015) A novel phosphodiesterase-5 inhibitor: Yonkenafil modulates neurogenesis, gliosis to improve cognitive function and ameliorates amyloid burden in an APP/PS1 transgenic mice model. Mech Ageing Dev 150:34-45. CrossRef Medline 